\title{
UTILITY OF FUNCTIONALIZED AGAROSE NANOPARTICLES IN HYDROLYZING LACTOSE IN BATCH REACTORS FOR DAIRY INDUSTRIES
}

\author{
Shakeel Ahmed Ansaria,*, Syed Ismail Ahmad ${ }^{\mathrm{b}}$, Mohammad Alam Jafria, Muhammad Imran Naseer ${ }^{\mathrm{a}}$ and Rukhsana Satar $^{\mathrm{c}}$ \\ aCenter of Excellence in Genomic Medicine Research, King Abdulaziz University, Jeddah-21589, Kingdom of Saudi Arabia \\ ${ }^{b}$ Physics Division, Department of Basic Sciences, Ibn Sina National College for Medical Studies, Jeddah-21418, Kingdom of \\ Saudi Arabia \\ 'Department of Biochemistry, Ibn Sina National College for Medical Sciences, Jeddah-21418, Kingdom of Saudi Arabia
}

Recebido em 22/10/2017; aceito em 13/12/2017; publicado na web em 01/02/2018

\begin{abstract}
The present study investigates the synthesis of agarose nanoparticles (ANPs) and its surface modification by galactose for the immobilization of $\beta$-galactosidase. Galactose modified ANPs retained $91 \%$ enzyme activity upon immobilization. Optimum pH (4.5) and temperature $\left(50{ }^{\circ} \mathrm{C}\right)$ remains unchanged after immobilization. However, immobilized enzyme retained greater catalytic activity against lower and higher, $\mathrm{pH}$ and temperature ranges. Immobilized $\beta$-galactosidase retained $89 \%$ biocatalytic activity even at $4 \%$ galactose concentration as compared to enzyme in solution, and exhibited $81 \%$ activity even after seventh repeated uses. Immobilized enzyme hydrolyzed greater amount of lactose at higher temperatures as compared to $\beta$-galactosidase in solution, thereby suggesting its potential application in obtaining lactose-free dairy products at large scale.
\end{abstract}

Keywords: agarose nanoparticles; dairy industry; galactose; lactose hydrolysis.

\section{INTRODUCTION}

Lactose is a disaccharide that is abundant in mammalian milk and is essential for the nourishment of newborn infants. ${ }^{1,2}$ It is hydrolyzed by the intestinal brush-border enzyme, $\beta$-galactosidase, into absorbable sugars, namely glucose and galactose. It should be noted that competing for the enzyme active site, galactose is known as a strong competitive inhibitor for $\beta$-galactosidase. ${ }^{3}$ However, there are few reports which suggest that glucose acts as a strong inhibitor for $\beta$-galactosidase from species such as Lactobacillus reuteri, Bifidobacterium longum $\mathrm{BCRC} 15708$, Thermus sp. $\mathrm{T}_{2}$ and Kluyveromyces lactis, ${ }^{4-7}$ and showed uncompetitive inhibition for Caldicellulosiruptor saccharolyticus $\beta$-galactosidase. ${ }^{8}$ Thus, due to the presence of these product inhibitors, it is difficult to achieve complete hydrolysis of lactose which ultimately decreased the hydrolytic rate or even stops the reaction completely. Hence, several efforts were raised in the recent past to engineer $\beta$-galactosidase for removing product inhibition in order to obtain greater yield of lactose-free dairy products..$^{9-12}$

Last decade witnessed the profound impact of heterogeneous catalysis on chemicals and fuels production, environmental protection, remediation, processing of consumer products and development of advanced materials. ${ }^{13}$ Improvement in catalytic activity and selectivity holds the key for developing efficient catalytic processes. This can be achieved by tailoring materials with desired microstructure and active component dispersion in order to bring significant advances in the field of catalysis. ${ }^{14}$ In this regard, nanostructured materials have opened up new dimension in catalytic research because of their capabilities of manipulating materials microstructure and compositional variation at nanometer scale. ${ }^{15}$

Owing to their known health benefits and prospects in improving the quality of food, lactose-free dairy products have attracted the attention of researchers in the field of functional foods. Hence, they are currently used as low-calorie sweeteners in fermented milk products, confectioneries, breads and beverages. ${ }^{16}$ Moreover, with

*e-mail: shakeel.cegmr@gmail.com the growing expansion of biotechnology industry, it is becoming increasingly evident to design efficient and novel procedure for obtaining such products with improved quality and at less cost. ${ }^{17}$ It should be noted that major drawback associated in using free enzymes for biotechnological applications involves their instability at different $\mathrm{pH}$ and temperature environments. Furthermore, non-reuse of free enzymes limits their use in above-mentioned fields due to high cost of enzyme production and purification. ${ }^{18}$ Hence, immobilization of enzyme on solid carriers is suggested for improving their stability and reusability properties.

Several attempts were made in the recent past to immobilize $\beta$-galactosidase on cotton cloth, ${ }^{19}$ anion-exchange resin ${ }^{20}$ and cellulose acetate-polymethylmethacrylate membrane. ${ }^{21}$ Moreover, with the emergence and increase of microbial contamination in the immobilized system and the continuous emphasis on health care costs, many researchers have tried to develop new and effective nanoparticle based $\beta$-galactosidase immobilized system that are free of microbial resistance and reduced product inhibition which could facilitate the continuous and long-term processing of the biocatalyst, and ultimately reduce their cost in biotechnology industries. ${ }^{3,22}$ This is a growing field and need more investigation to bring new efficient catalytic process to practice.

Hence, in the present study, efforts were raised to immobilize $\beta$-galactosidase on the synthesized agarose nanoparticles (ANPs). This method has shown many interesting and valuable advantages: (1) inexpensive starting material (2) a rapid and simple method (3) improved stability against various physical and chemical denaturants, and product mediated inhibition by galactose. The biotechnological potential of immobilized enzyme was shown by the production of lactose-free dairy products at $50^{\circ} \mathrm{C}$ and $60{ }^{\circ} \mathrm{C}$.

\section{MATERIALS AND METHODS}

\section{Materials}

Agarose, dimethyl sulfoxide, galactose, Aspergillus oryzae $\beta$-galactosidase and polyvinyl alcohol were obtained from Sigma 
Aldrich. Buffers of different $\mathrm{pH}$ values, n-butanol, $o$-nitrophenyl $\beta$-D-galctopyranoside (ONPG) and ethanolamine were obtained from Merck. All the chemicals were used as received without any pretreatment.

\section{Synthesis and surface modification of agarose nanoparticles}

Agarose nanoparticles [ANPs] were prepared with slight modification according to the method described. ${ }^{23}$ The obtained powder was washed with water, freeze-dried and compressed at room temperature for few minutes and left at room temperature for two hours. The synthesized ANPs were washed with deionized water and recovered by centrifugation at $1800 \mathrm{rpm}$ for $10 \mathrm{~min}$. The washed ANPs were then suspended in $100 \mathrm{mM}$ galactose in a shaker at $250 \mathrm{rpm}$ for 4 $\mathrm{h}$. The activated support was removed by centrifugation, washed twice with deionized water to remove traces of galactose and subsequently washed with assay buffer (100 mM sodium acetate buffer, $\mathrm{pH} 4.5$ ), and the resulting galactose modified agarose nanoparticles were used for further studies.

\section{Immobilization of $\beta$-galactosidase}

$\beta$-galactosidase (12000 U) was mixed independently with ANPs $(1.0 \mathrm{~g})$ and galactose modified ANPs $(1.0 \mathrm{~g})$, and this mixture was stirred overnight in sodium acetate buffer, $\mathrm{pH} 4.5$ at $4{ }^{\circ} \mathrm{C}$. Immobilized $\beta$-galactosidase was collected by centrifugation at $300 \mathrm{rpm}$ for $20 \mathrm{~min}$. Matrix bound $\beta$-galactosidase was washed thrice with $100 \mathrm{mM}$ sodium acetate buffer, $\mathrm{pH} 4.5$ and finally suspended in the same buffer and stored at $4{ }^{\circ} \mathrm{C}$ for further use. Activity of enzyme and the supernatant was checked according to the procedure discussed below.

\section{Enzyme assay}

The synthetic substrate $o$-nitrophenyl $\beta$-D-galactopyranoside (ONPG) was used for its simplicity in terms of assay protocol. Hydrolysis of $\beta$-galactosidase was calculated by continuously shaking an assay volume of $2.0 \mathrm{~mL}$ containing $1.79 \mathrm{~mL}$ of $100 \mathrm{mM}$ sodium acetate buffer ( $\mathrm{pH} 4.5$ ), $100 \mu \mathrm{L}$ suitably diluted $\beta$-galactosidase and $0.2 \mathrm{~mL}$ of $2.0 \mathrm{mM}$ ONPG for $15 \mathrm{~min}$ at $40{ }^{\circ} \mathrm{C}$. The reaction was stopped by adding $3.0 \mathrm{~mL}$ of $1.0 \mathrm{M}$ sodium carbonate solution and product formed was measured spectrophotometrically at $405 \mathrm{~nm} .^{24}$

\section{Effect of product inhibition}

The activity of soluble and immobilized $\beta$-galactosidase preparations $(25 \mu \mathrm{L})$ was determined in the presence of increasing concentrations of galactose $(1.0-5.0 \%, \mathrm{w} / \mathrm{v})$ in $0.1 \mathrm{~mol} \mathrm{~L}^{-1}$ sodium acetate buffer, $\mathrm{pH} 4.5$ at $40^{\circ} \mathrm{C}$ for $1 \mathrm{~h}$. The activity of enzyme without added galactose was considered as control (100\%) for the calculation of remaining percent activity.

\section{Stability studies of ANPs bound $\beta$-galactosidase}

Enzyme activity of soluble and immobilized $\beta$-galactosidase preparations $(25 \mu \mathrm{L})$ was assayed in buffers of different $\mathrm{pH}$ (pH 3.0-8.0). The buffers used were glycine-HCl (3.0), sodium acetate $(\mathrm{pH} 4.0-6.0)$ and Tris- $\mathrm{HCl}(7.0,8.0)$. Molarity of the buffer was $0.1 \mathrm{~mol} \mathrm{~L}^{-1}$. The activity expressed at $\mathrm{pH} 4.5$ was considered as control $(100 \%)$ for the calculation of remaining percent activity. In another experiment, effect of temperature on soluble and immobilized $\beta$-galactosidase $(25 \mu \mathrm{L})$ was studied by measuring their activity at various temperatures $\left(30-70{ }^{\circ} \mathrm{C}\right)$. The enzyme was incubated at various temperatures in $0.1 \mathrm{~mol} \mathrm{~L}^{-1}$ sodium acetate buffer, $\mathrm{pH}$ 4.5 for $15 \mathrm{~min}$ and the reaction was stopped by adding $3.0 \mathrm{~mL}$ of $1.0 \mathrm{~mol} \mathrm{~L}^{-1}$ sodium carbonate solution. The activity obtained at $50{ }^{\circ} \mathrm{C}$ was considered as control (100\%) for the calculation of remaining percent activity.

Soluble and immobilized $\beta$-galactosidase preparations were stored at $4{ }^{\circ} \mathrm{C}$ in $0.1 \mathrm{~mol} \mathrm{~L}^{-1}$ sodium acetate buffer, $\mathrm{pH} 4.5$ for 2 months. Aliquots from each preparation $(25 \mu \mathrm{L})$ were taken in triplicates at the gap of 10 days and were then analyzed for the remaining activity. The activity determined on the first day was taken as control (100\%) for the calculation of remaining percent activity.

Immobilized $\beta$-galactosidase preparations $(100 \mu \mathrm{L})$ were taken in triplicates for assaying the activity of enzyme. After each assay, immobilized enzyme was taken out from assay tubes and was washed and stored in $0.1 \mathrm{~mol} \mathrm{~L}^{-1}$ sodium acetate buffer, $\mathrm{pH} 4.5$ overnight at $4{ }^{\circ} \mathrm{C}$ for 7 successive days. The activity determined on the first day was considered as control (100\%) for the calculation of remaining percent activity.

\section{Lactose hydrolysis}

Lactose solution $\left(250 \mathrm{~mL}, 0.1 \mathrm{~mol} \mathrm{~L}^{-1}\right)$ was independently incubated with soluble enzyme and $\beta$-galactosidase bound to galactose modified ANPs (250 U) and stirred continuously in water bath at $50{ }^{\circ} \mathrm{C}$ and $60{ }^{\circ} \mathrm{C}$ for varying times. The aliquots were taken at different times and assayed for the formation of glucose by glucose oxidase-peroxidase assay kit.

\section{Estimation of protein}

Protein concentration was determined by using bovine serum albumin as a standard. ${ }^{25}$

\section{Statistical analysis}

Each value represents the mean for three independent experiments performed in triplicates, with average standard deviations $<5 \%$. The data expressed in various studies was plotted using Sigma Plot-9. Data was analyzed by one-way ANOVA. P-values $<0.05$ were considered statistically significant.

\section{RESULTS AND DISCUSSION}

Owing to their known health benefits and prospects in improving the quality of food, lactose-free dairy products have attracted the attention of researchers in the field of functional foods. Hence, they are currently used as low-calorie sweeteners in fermented milk products, confectioneries, breads and beverages. ${ }^{16}$ Moreover, with the growing expansion of biotechnology industry, it is becoming increasingly evident to design efficient and novel procedure for obtaining such products with improved quality and at less cost. ${ }^{16}$

It should be noted that agarose nanoparticles (ANPs) have been successfully utilized earlier for the administration of therapeutic proteins and peptides. ${ }^{23,26,27}$ Hence, in the present study, efforts were raised to utilize these synthesized ANPs in biotechnology industries. The precipitated ANPs possess larger crystalline size at room temperature $\left(30 \pm 2{ }^{\circ} \mathrm{C}\right)$ which arises from the fact that small particles are preferred in reaction dynamics with larger surface energy, while large particles are thermodynamically favored with larger volume energy (Oswald ripening theory). The designed ANPs were modified by galactose to minimize the competitive inhibition offered by it for obtaining excellent yield of lactose-free dairy products. It was hypothesized that immobilization of $\beta$-galactosidase on the modified 
nanomatrix occurred due to functionalization by chemical bond and not by strong adsorption (Figure 1).

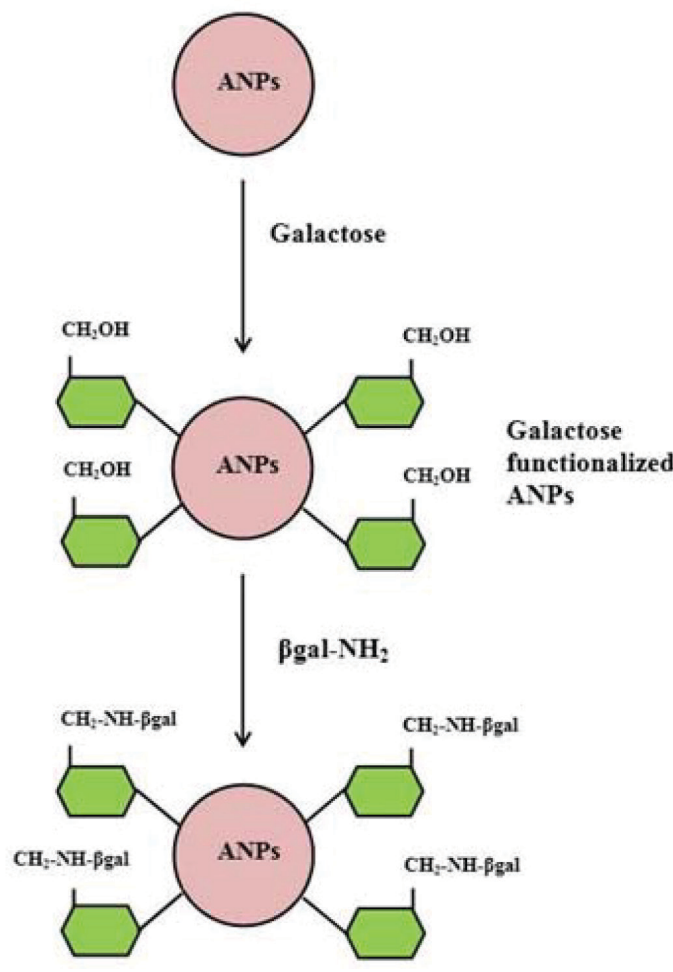

Figure 1. Scheme of functionalization of ANPs and attachment of $\beta$-galactosidase

The modified nanomatrix retained $91 \%$ enzyme activity upon immobilization (Table 1). Hence, the developed immobilized system was quite mild and promoted very small distortion of the active site of the enzyme. Due to easy production, non-toxic nature and greater specificity of the nanosupport, it might serve as a powerful biorecognition probe in biosensor applications.

The important difference achieved in using galactose modified ANPs was improved stability of $\beta$-galactosidase towards increased acidic and more alkaline conditions after immobilization. At various $\mathrm{pH}$ values, enzyme bound to galactose modified ANPs was more stable than free enzyme as shown in Figure 2. It should be noted that in more acidic conditions such as $\mathrm{pH} 3.0$, free $\beta$-galactosidase loses more than $65 \%$ activity, while immobilized enzyme retained $84 \%$ activity. Under more alkaline conditions such as $\mathrm{pH} 8$, free enzyme lost $83 \%$ activity, while the immobilized enzyme retained $46 \%$ activity, thereby indicating that the resistance of $\beta$-galactosidase to acid and basic denaturation was increased remarkably after immobilization. Immobilization resulted in an improved activity of enzyme bound to galactose modified ANPs due to lesser alteration/distortion produced in the tertiary structure of enzyme thereby providing significant stabilization to the enzyme against heat induced inactivation. It was observed that soluble enzyme exhibited $35 \%$ activity at $70^{\circ} \mathrm{C}$ while $\beta$-galactosidase bound to galactose modified ANPs retained $74 \%$ activity under identical conditions (Figure 3 ).

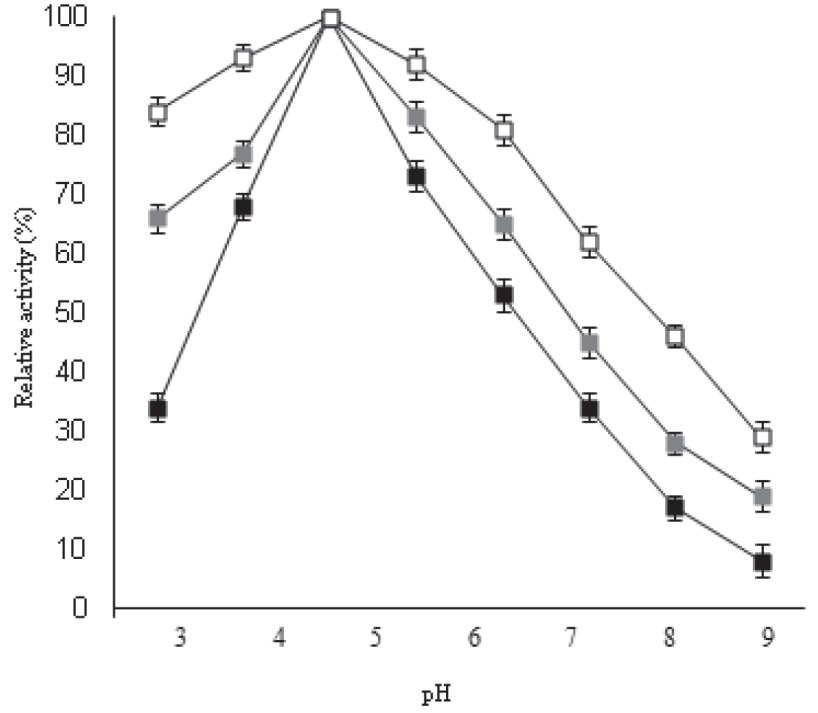

Figure 2. pH-activity profiles for soluble $\beta$-galactosidase and enzyme immobilized on ANPs, and galactose modified ANPs

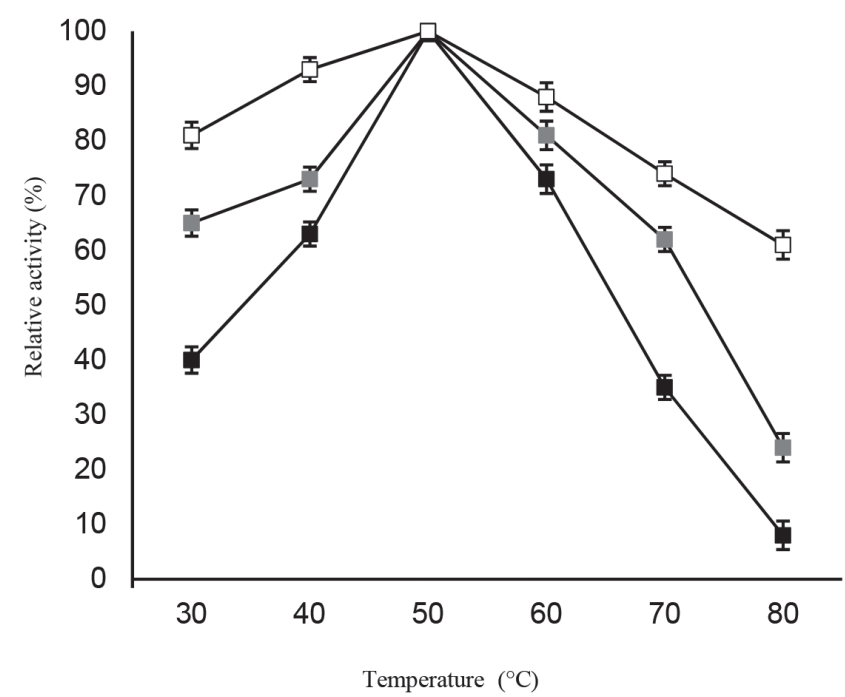

Figure 3. Temperature-activity profiles for soluble $\beta$-galactosidase and enzyme immobilized on ANPs, and galactose modified ANPs

Engineering of several fungal and microbial $\beta$-galactosidases for minimizing galactose mediated product inhibition have been a topic of great interest for producing lactose-free dairy products efficiently and in large amounts. ${ }^{8}$ It is noteworthy to mention that galactose acts as a strong competitive inhibitor from Aspergillus oryzae which have resulted in reduced lactose hydrolysis for the developed immobilized $\beta$-galactosidase system. ${ }^{22,28,29}$ This study is of first kind to suggest that galactose can be used effectively for modifying the surface of ANPs. It was observed that $\beta$-galactosidase bound to galactose modified ANPs showed greater resistance to product inhibition mediated by galactose even at $5 \%$ concentration (Figure 4 ). Soluble $\beta$-galactosidase showed $47 \%$ activity in the presence of $3.0 \%$ galactose, while ANP bound

Table 1. $\beta$-galactosidase immobilized on galactose modified ANPs

\begin{tabular}{ccccc}
\hline \multirow{2}{*}{$\begin{array}{c}\text { Enzyme activity loaded } \\
\text { (X Units) }\end{array}$} & $\begin{array}{c}\text { Enzyme activity in washes } \\
\text { (Y Units) }\end{array}$ & \multicolumn{2}{c}{ Activity bound/g of galactose modified ANPs } & Activity yield (\%) \\
\cline { 3 - 4 } B/A x 100 & Theoretical (X-Y)=A & Actual=B & $10505 \pm 0.32$ & $91 \pm 0.25$ \\
\hline $12000 \pm 0.45$ & $456 \pm 0.37$ & $11544 \pm 0.42$ & \\
\hline
\end{tabular}

Each value represents the mean for three independent experiments performed in triplicates, with average standard deviations, $<5 \%$. 
$\beta$-galactosidase exhibited much higher enzyme activity, $91 \%$ at the same concentration of galactose.

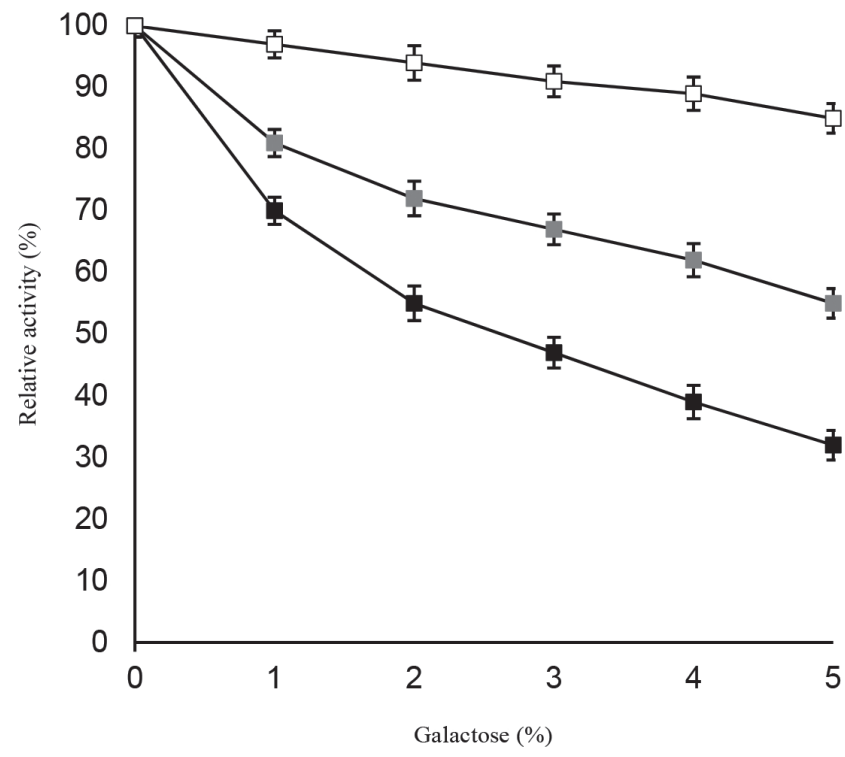

Figure 4. Effect of galactose on soluble $\beta$-galactosidase and enzyme immobilized on ANPs, and galactose modified ANPs

Table 2 depicted the hydrolysis of lactose in lab-scale batch reactor. It was observed that rate of hydrolysis was more in case of free enzyme for first few hours as compared to $\beta$-galactosidase covalently attached to galactose modified ANPs. It was due to the fact that soluble enzyme was more accessible for hydrolysis of lactose for first few hours but after prolonged time intervals, activity of soluble enzyme decreased faster as compared to the enzyme bound to galactose modified ANPs. Moreover, greater percent of lactose hydrolysis was obtained by this immobilized enzyme at $50{ }^{\circ} \mathrm{C}$ because of similar temperature-optima of Aspergillus oryzae $\beta$-galactosidase. It has been observed that lactose hydrolysis obtained after $4 \mathrm{~h}$ was $64 \%$ by soluble $\beta$-galactosidase at $50{ }^{\circ} \mathrm{C}$ while the maximum hydrolysis obtained by it was $75 \%$ after $8 \mathrm{~h}$ under identical conditions. At a higher temperature of $60{ }^{\circ} \mathrm{C}, \beta$-galactosidase bound to galactose modified ANPs exhibited $81 \%$ lactose hydrolysis after $8 \mathrm{~h}$ as compared to $\mathrm{S} \beta \mathrm{G}$. Since enzyme immobilized on galactose modified ANPs showed greater activity at higher temperatures and was less affected with galactose concentration as compared to its soluble counterpart, this method provided cost effective advantage for obtaining lactose-free products in an economically viable enzyme catalyzed process.

The developed immobilized $\beta$-galactosidase system imparts profound stability to the enzyme at $4{ }^{\circ} \mathrm{C}$ even after 2 months of storage (Figure 5), thereby suggesting the stable molecular confinement of enzyme structure and function achieved henceforth. ${ }^{30}$ Figure 6 showed that enzyme bound to galactose modified ANPs retained more than $80 \%$ of activity after $7^{\text {th }}$ batch uses. Immobilization improved the efficiency of enzyme and also provided a method for continuous reaction thereby suggesting its possible repeated use in biotechnology industries.

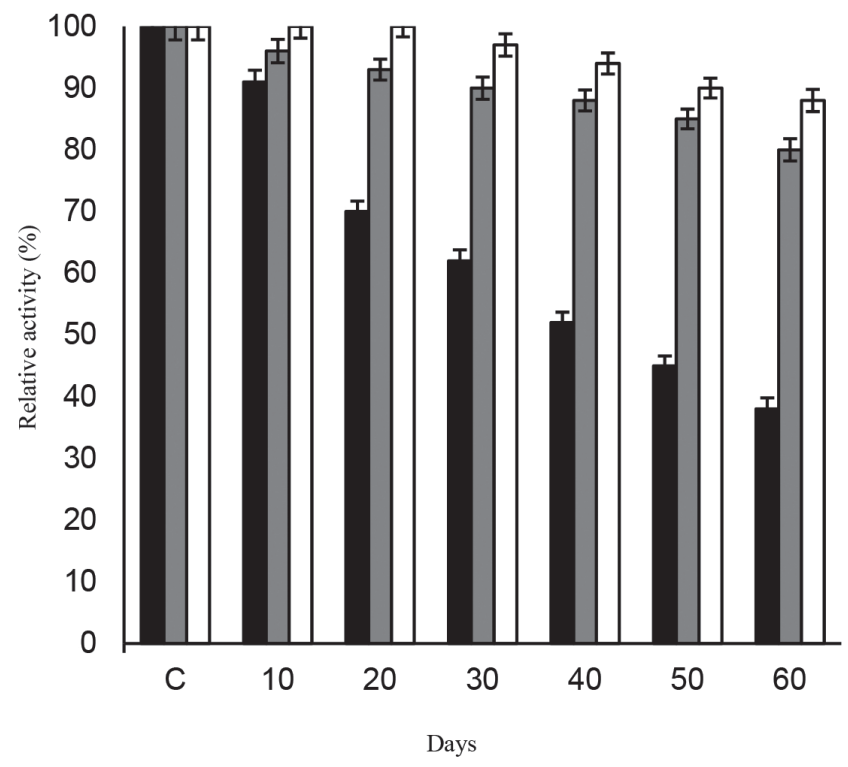

Figure 5. Storage stability of soluble $\beta$-galactosidase and enzyme immobilized on ANPs, and galactose modified ANPs

Table 2. Hydrolysis of lactose by soluble $\beta$-galactosidase and enzyme bound to galactose modified ANPs in batch process at different temperatures

\begin{tabular}{|c|c|c|c|c|}
\hline \multirow{3}{*}{ Time (h) } & \multicolumn{4}{|c|}{ Lactose hydrolysis } \\
\hline & \multicolumn{2}{|c|}{$50{ }^{\circ} \mathrm{C}$} & \multicolumn{2}{|c|}{$60^{\circ} \mathrm{C}$} \\
\hline & Soluble enzyme & $\begin{array}{l}\text { Enzyme bound to galactose } \\
\text { modified ANPs }\end{array}$ & Soluble enzyme & $\begin{array}{l}\text { Enzyme bound to galactose } \\
\text { modified ANPs }\end{array}$ \\
\hline 0 & Not analyzed & Not analyzed & Not analyzed & Not analyzed \\
\hline 1 & $45 \pm 0.22$ & $39 \pm 0.32$ & $40 \pm 0.24$ & $34 \pm 0.31$ \\
\hline 2 & $49 \pm 0.32$ & $57 \pm 0.27$ & $46 \pm 0.31$ & $45 \pm 0.26$ \\
\hline 3 & $58 \pm 0.28$ & $66 \pm 0.18$ & $54 \pm 0.29$ & $61 \pm 0.18$ \\
\hline 4 & $64 \pm 0.24$ & $71 \pm 0.42$ & $61 \pm 0.41$ & $66 \pm 0.33$ \\
\hline 5 & $68 \pm 0.46$ & $79 \pm 0.27$ & $63 \pm 0.39$ & $71 \pm 0.39$ \\
\hline 6 & $71 \pm 0.38$ & $88 \pm 0.28$ & $65 \pm 0.27$ & $74 \pm 0.28$ \\
\hline 7 & $73 \pm 0.18$ & $91 \pm 0.16$ & $65 \pm 0.17$ & $74 \pm 0.12$ \\
\hline 8 & $75 \pm 0.32$ & $93 \pm 0.32$ & $67 \pm 0.11$ & $79 \pm 0.24$ \\
\hline 9 & $75 \pm 0.25$ & $93 \pm 0.15$ & $67 \pm 0.24$ & $81 \pm 0.18$ \\
\hline 10 & $75 \pm 0.19$ & $93 \pm 0.35$ & $67 \pm 0.42$ & $81 \pm 0.42$ \\
\hline
\end{tabular}

Lactose hydrolysis was performed as described in text. Each value represents the mean for three independent experiments performed in triplicates, with average standard deviations, $<5 \%$. 


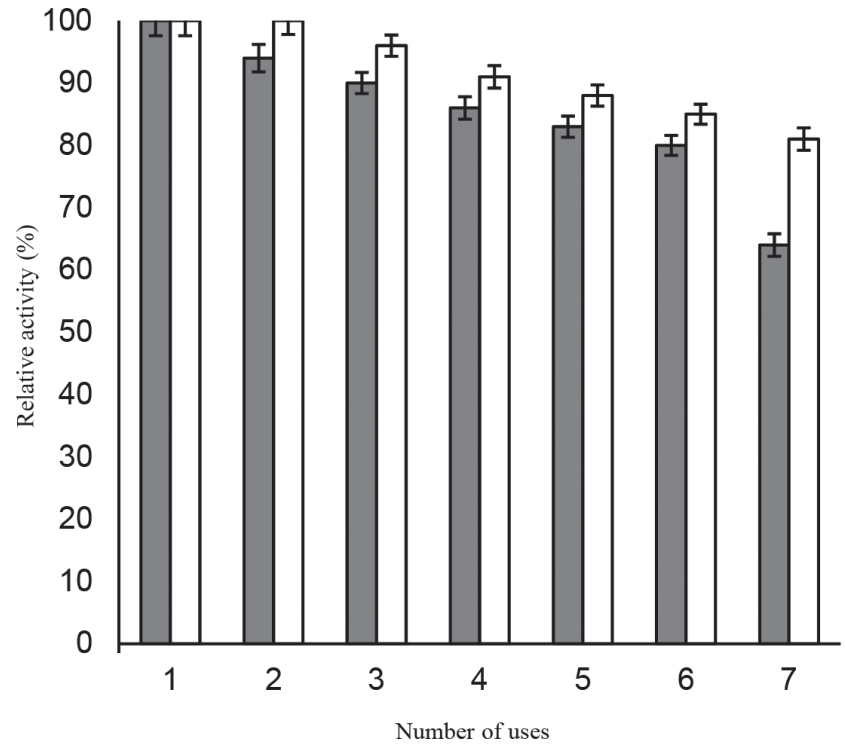

Figure 6. Reusability of $\beta$-galactosidase bound to ANPs and galactose modified ANPs

\section{CONCLUSION}

The present study utilizes a simple and inexpensive procedure of synthesizing agarose nanoparticles for exploiting it as a nanomatrix for immobilizing $\beta$-galactosidase. Immobilized enzyme exhibited marked stabilization against physical denaturation (at various $\mathrm{pH}$ and temperature ranges), and against galactose mediated product inhibition. ANPs offered unique opportunities in providing shape and size selectivity for molecules too large to react within the framework of conventional nanostructured materials, thereby serving as stable catalytic supports. Moreover, immobilized enzyme system obtained on galactose modified ANPs does not seem to be restricted by diffusional limitations and hence can be exploited in biotechnological process for producing lactose-free dairy products.

\section{REFERENCES}

1. Lomer, M. C. E.; Parks, G. C.; Sanderson, J. D.; Aliment. Pharmacol. Ther. 2008, 27, 93.

2. Mattar, R.; Mazo, D. F. C.; Carrilho, F. J.; Clin. Exp. Gastroenterol. 2012, 5,113

3. Ansari, S. A.; Satar, R.; Zaidi, S. K.; Ahmad, A.; Int. Scholarly Res. Not. 2014, 2014, 163987
4. Pessela, B. C. C.; Mateo, C.; Carrascosa, A. V.; Vian, A.; Garcı, J. L.; Rivas, G.; Alfonso, C.; Guisan, J. M.; Fernandez-Lafuente, R.; Biomacromolecules 2003, 4, 107.

5. Mateo, C.; Monti, R.; Pessela, B. C. C.; Fuentes, M.; Torres, R.; Guisan, J. M.; Fernandez-Lafuente, R.; Biotechnol. Prog. 2004, 20, 1259.

6. Nguyen, T. H.; Splenchtna, B.; Steinbock, M.; Kneifel, W.; Lettner, H. P.; Kulbe, K. D.; Haltrich, D.; J. Agric. Food Chem. 2006, 54, 4989.

7. Hsu, C. A.; Lee, S. L.; Chou, C. C.; J. Agric. Food Chem. 2007, 55, 2225.

8. Park, A-R.; Oh, D-K.; Appl. Microbiol. Biotechnol. 2010, 55, 1279.

9. Boyaci, I. H.; Bas, D.; Dudak, F. C.; Topcu, A.; Saldamli, I.; Seker, U. O. S.; Tamerler, C.; Food Biotechnol. 2006, 20, 79.

10. Hu, X.; Robin, S.; O'Connell, S.; Walsh, G.; Wall, J. G.; Appl. Microb. Biotechnol. 2010, 87, 1773.

11. Zhang, X.; Li, H.; Li, C-J.; Ma, T.; Li, G.; Liu, Y-H.; BMC Microbiol. 2013, 13, 237

12. Satar, R.; Ansari, S.A.; Braz. J. Chem. Eng. 2017, 34, 475.

13. Johnson, B. J.; Algar, W. R.; Malanoski, A. P.; Ancona, M. G.; Medintz, I. L.; Nano Today 2014, 9, 102.

14. Kango, S.; Kalia, S.; Celli, A.; Njuguna, J.; Habibi, Y.; Kumar, R.; Prog. Polym. Sci. 2013, 38, 1232.

15. Zaera, F.; Chem. Soc. Rev. 2013, 42, 2746.

16. Grosling, A.; Stevens, G. W.; Barber, A. R.; Kentish, S. E.; Gras, S. L.; Food Chem. 2010, 121, 307.

17. Sangwan, V.; Tomar, S. K.; Singh, R.; Singh, A. K.; Ali, B.; J. Food Sci. 2011, 76, 103

18. Gulec, H. A.; Gurdas, S.; Albayrak, N.; Mutlu, M.; Biotechnol. Bioproc. Eng. 2010, 15, 1006.

19. Albayrak, N.; Yang, S. T.; Biotechnol. Bioeng. 2002, 77, 8.

20. Engel, L.; Schneider, P.; Ebrahim, M.; Czermak, P.; Open Food Sci. J. 2007, $1,17$.

21. Oliviera, C.; Guimaraes, P. M. R.; Domingues, L.; Biotechnol. Adv. 2011, 29, 600 .

22. Ansari, S. A.; Satar, R.; Zaidi, S. K.; Alqahtani, M. H.; Naseer, M. I.; Karim, S.; Rasool, M.; Food Bioprod. Proc. 2015, 98, 298.

23. Wang, N.; Wu, X. S.; Pharm. Dev. Technol. 1997, 2, 135.

24. Ansari, S.A.; Satar, R.; Alam, F.; Alqahtani, M. H.; Chaudhary, A. G.; Naseer, M. I.; Karim, S.; Sheikh, I.; Proc. Biochem. 2012, 47, 2427.

25. Bradford, M. M.; Anal. Biochem. 1976, 72, 248.

26. Wang, N.; Wu, X. S.; Mesiha, M.; Pharm. Res. 1995, 12, S257.

27. Kunkel, A.; Asuri, J. P.; PLoS One 2014, 9, e86785.

28. Zhou, Q. Z.; Chen, X. D.; Li, X.; Biotechnol. Bioeng. 2003, 20, 127.

29. Mammarella, E. J.; Rubiolo, A. C.; Proc. Biochem. 2006, 41, 1627.

30. Kishore, D.; Talat, M.; Srivastava, O. N.; Kayastha, A. M.; PLoS One 2012, 7, e40708. 